\title{
Assessment of Mechanical and Morphological Properties of New Poly Lactic Acid (PLA) / Wood Fibers / Nanographene Composite
}

\section{Procjena mehaničkih i morfoloških svojstava kompozita proizvedenih od polilaktičke kiseline i drvnih vlakana s dodatkom nanografena}

\author{
Original scientific paper • Izvorni znanstveni rad \\ Received-prispjelo: 6. 6. 2017. \\ Accepted-prihvaćeno: 23. 5. 2018. \\ UDK: $630 * 863.31$ \\ doi:10.5552/drind.2018.1735
}

\begin{abstract}
The present study analyzed the effect of nanographene (NG) application at three rates $(0.75$, 1.5 , and $3 \%$ ) on the production of PLA85/F15 and PLA70/F30 composites. The incorporation of NG into the $P L A$ wood fiber composites significantly improved the tensile and bending properties. The results indicated that composites made from PLA68.5/F30/NG1.5 had the highest tensile and bending properties. Furthermore, it was revealed that the addition of fibers to PLA decreased the composite impact strength in comparison with pure $P L A$, whereas the addition of NG improved its impact strength, but not as much as pure PLA. The highest impact strength was observed in the composites containing $15 \%$ fibers and $1.5 \% \mathrm{NG}$ (PLA83.5/F15/NG1.5 composites). The composites made from $30 \%$ wood fiber and $1.5 \%$ (PLA68.5/F30/NG1.5 composites) NG had the best interfacial surface between the wood fiber and the matrix of composites.
\end{abstract}

Keywords: Polylactic acid, wood fiber, nanographene, mechanical properties

SAŽETAK • U radu je analiziran učinak nanografena (NG), dodanoga u različitim količinama (0,75, 1,5 i $3 \%)$, na svojstva kompozita proizvedenih od polilaktične kiseline (PLA) i drvnih vlakana (F) (kompoziti PLA85/F15 $i$ PLA70/F30). Ugradnjom NG-a u kompozite PLA/F znatno su poboljšana vlačna i savojna svojstva kompozita. Rezultati su pokazali da su kompoziti s dodatkom 1,5\% NG-a (PLA68.5/F30/NG1.5) imali najbolja vlačna i savojna svojstva. Nadalje, iz rezultata se može zaključiti da se dodavanjem drvnih vlakana u PLA smanjuje otpornost kompozita na udarce u usporedbi s čistim PLA, a dodavanjem NG-a poboljšava se otpornost kompozita na udar-

\footnotetext{
Authors are Ph.D. student, assistant professor, professor and associate professor at Department of Wood and Paper Science and Technology, College of Agriculture and Natural Resources, Science and Research Branch, Islamic Azad University, Tehran, Iran. ${ }^{2}$ Author is professor at Department of Processing, Iran Polymer and Petrochemical Institute (IPPI), P.O. Box 14965.115, Tehran, Iran.

Autori su doktorand, docent, profesor i izvanredni profesor Odjela za znanost i tehnologiju drva i papira, Fakultet za poljoprivredu i prirodne resurse, Islamsko sveučilište $\mathrm{Azad}$, Teheran, Iran. ${ }^{2}$ Autor je profesor Odjela za obradu, Iranski institut za polimere i petrokemiju, Teheran, Iran.
} 
ce. Međutim, ta je otpornost i dalje manja od otpornosti kompozita od čistog PLA. Najveća otpornost na udarce zabilježena je za kompozite koji sadržavaju $15 \%$ drvnih vlakana i 1,5\% NG-a (kompoziti PLA83.5/F15/NG1.5). Kompoziti proizvedeni od $30 \%$ drvnih vlakana i 1,5\% NG-a (kompoziti PLA68.5/F30/NG1.5) imali su najbolju površinu između drvnih vlakana i matrice kompozita.

Ključne riječi: polilaktična kiselina, drvna vlakna, nanografen, mehanička svojstva

\section{INTROUDUCTION}

\section{UVOD}

As environmental issues are growingly addressed, the use of materials, which are helpful for sustainable development, increases worldwide. One of the most significant improvements in the recent years has been the use of biodegradable polymers instead of crude oil-based polymers such as polypropylene and polyethylene. Recently, one of the most important biodegradable polymers has been poly lactic acid (PLA).

PLA has some advantages, including relatively high mechanical strength and processing feasibility on most equipment, but it needs to be strengthened for practical uses owing to its inherent brittleness (Petinakis et al., 2009). The use of natural fibers can be a proper solution for strengthening its mechanical properties (Puglia et al., 2004; Mohanty et al., 2000) and reducing its production costs (Chaharmahali et al., 2014). Lignocellulosic fibers are a suitable substitution for traditional synthetic fibers in the production of polymer composite, because they feature such advantages as low density, renewability, biodegradability, wide availability, and low cost (Kim et al., 2009).

In spite of the advantages of PLA for producing PLA/wood fiber composite, some problems have been reported during the processing, including low fibers/ matrix interphase adhesion for PLA/natural fibers composite (Bledzki et al., 2010). The use of nanoparticles in trace quantities is a solution to improve these properties, so that it has been demonstrated to be highly effective. Good dispersion of lignocellulosic fibers is guaranteed in polymers by the use of nanoparticles because of their high surface area, low density and high Young`s modulus. Among a wide range of nanoparticles, the use of NG has been considerably increased because of their unique mechanical and physical properties. It has been reported that the mechanical and electrical properties of NG-based composites are much better than nanoclay- and other nanocarbon-based composites. It has been shown that polylactic acid (PLA)/ wood fiber /nanographene has better mechani- cal, thermal, gas penetration and electrical properties than pure polymer due to the extraordinary properties of graphene in comparison with polymer (Balandin et al., 2008; Ansari and Giannelis, 2009). Moreover, it has been reported that the improvement of mechanical and electrical properties of polymer/graphene composites has been much higher than those of nanoclay and other carbon filler-based polymer composites (Kim et al., 2009). Despite relatively good graphene distribution in polyethylene matrix, a $20 \%$ improvement is observed in tensile modulus and a $13 \%$ improvement is observed in tensile strength (Lin et al., 2011).

The objective was to add NG to PLA/wood fiber composite and to improve mechanical and morphological properties.

\section{MATERIALS AND METHODS 2. MATERIJALI I METODE}

The present study used the natural fibers obtained from MDF factory as filler for PLA matrix. Then, NG was added to the material at the rates of $0.75,1.5$, and $3 \%$.

\subsection{Materials \\ 2.1. Materijali}

The PLA, which was used as the matrix, was procured from Chinese Shanghai Freeman Chemical Co., Ltd. It had the density of $1.25 \mathrm{~g} \cdot \mathrm{cm}^{-3}$, the melting point of $150-170{ }^{\circ} \mathrm{C}$, and the melting flow index (MFI) of $15-30 \mathrm{~g} \cdot 10 \mathrm{~min}^{-1}$. The fibers used in this study were a mixture of $70 \%$ broad-leaves from northern Iran gardens and $30 \%$ spruce fibers procured from Khazar (Caspian) MDF plant. Table 1 shows some details about fibers used in this study.

\subsubsection{Properties of nanographene 2.1.1. Svojstva nanografena}

The NG powder (grade AO-4) was procured from the Graphene Supermarket Co (USA). The average thickness and lateral size of $\mathrm{NG}$ was about $12 \mathrm{~nm}$ and $4.5 \mu \mathrm{m}$, respectively. The purity was $99.2 \mathrm{wt} \%$ and the specific surface area was less than $15 \mathrm{~m}^{2} / \mathrm{g}$.

Table 1 Details of fiber used in this study

Tablica 1. Podatci o upotrijebljenim vlaknima

\begin{tabular}{|l|l|}
\hline \multicolumn{1}{|c|}{$\begin{array}{c}\text { Fiber properties } \\
\text { Svojstva vlakana }\end{array}$} & \multicolumn{1}{c|}{ Value / Vrijednost } \\
\hline $\begin{array}{l}\text { Fiber type } \\
\text { izvor vlakana }\end{array}$ & $\begin{array}{l}\text { Seventy percent were derived from twigs of the pruned orange, tangerine and lemon trees in } \\
\text { orchards in Northern Iran } \\
\text { Thirty percent were derived from spruce twigs gathered from the forests in Northern Iran. } \\
70 \% \text { vlakana dobiveno je od grančica preostalih nakon orezivanja naranača, mandarina } i \\
\text { limuna u voćnjacima sjevernog Irana. } \\
30 \% \text { vlakana dobiveno je od smrekovih grančica prikupljenih } u \text { šumama sjevernog Irana. }\end{array}$ \\
\hline Density / gustoća & \multicolumn{1}{c|}{$0.36 \mathrm{~g} \cdot \mathrm{cm}^{3}$} \\
\hline Fiber length / duljina vlakana & $5-5.5 \mathrm{~mm}$ \\
\hline
\end{tabular}




\subsection{Methods}

\subsection{Metode}

\subsubsection{Composite fabrication}

\subsubsection{Proizvodnja kompozita}

According to Table 2, the materials composed of different rates of cellulosic fibers and NG and PLA were made by an inner mixer. Before the mixing process, the material was oven-dried for 24 hours at $75^{\circ} \mathrm{C}$ to remove the moisture. The mixture process was carried out by a mixer at three thermal rates of 170 , 175 , and $180^{\circ} \mathrm{C}$ at 30 rounds per minutes (rpm) for 11 minutes (Internal mixer, Brabender, 2002 element, the W50 model). Compression molding was used for fabricating the standard samples and doing various mechanical experiments. As pre-compression, the samples were heated to $180^{\circ} \mathrm{C}$ for 5-6 minutes. Then, they were compressed to $30 \mathrm{MPa}$ for 4-5 minutes. Afterwards, the pressure was slowly removed in 5-6 minutes and the temperature was decreased to ambient temperature (mini test press, Japan, 2002, theWCH model, pressure of 25-35 MPa).

Table 2 Composition of materials for the composites Tablica 2. Oznaka i sastav proizvedenih kompozita

\begin{tabular}{|l|l|l|l|}
\hline $\begin{array}{l}\text { Code } \\
\text { Oznaka }\end{array}$ & $\begin{array}{l}\text { PLA } \\
\text { wt \% }\end{array}$ & $\begin{array}{l}\text { Fibers } \\
\text { wt \% }\end{array}$ & $\begin{array}{l}\text { NG } \\
\text { wt \% }\end{array}$ \\
\hline PLA100 & 100 & 0 & 0 \\
\hline PLA85/F15 & 85 & 15 & 0 \\
\hline PLA84.25/F15/NG0.75 & 84.25 & 15 & 0.75 \\
\hline PLA83.5/F15/NG 1.5 & 83.5 & 15 & 1.5 \\
\hline PLA82/F15/NG3 & 82 & 15 & 3 \\
\hline PLA70/F30 & 70 & 30 & 0 \\
\hline PLA69.25/F30/NG0.75 & 69.25 & 30 & 0.75 \\
\hline PLA68.5/F30/NG 1.5 & 68.5 & 30 & 1.5 \\
\hline PLA67/F30/NG3 & 67 & 30 & 3 \\
\hline
\end{tabular}

PLA - Poly Lactic Acid / polilaktična kiselina, NG - nanographene / nanografen, F - Fiber / vlakna

\subsubsection{Mechanical experiments}

\subsubsection{Ispitivanje mehaničkih svojstava kompozita}

Bending and tensile strengths were tested at loading rate of $5 \mathrm{~mm} \cdot \mathrm{min}^{-1}$ by INSTRON machine (model 4489) in accordance with D790 and D638 procedures of the ASTM standard, respectively. Notched impact strength was tested by INSTRON machine (model 5102 , ZWICK Co.) in accordance with D256 procedure of the ASTM standard.

\subsubsection{Scanning Electron Microscopy}

\subsubsection{Skeniranje elektronskim mikroskopom}

Refraction sections of tensile samples were imaged by Scanning Electron Microscopy (SEM) (VEGA, ITESCAN Co., the Czech Republic). The microscope uses the voltage of $20 \mathrm{~W}$. Before shooting, the samples were covered (encrusted) with a $15 \mathrm{~nm}$ gold layer for five minutes by Covering Machine (Emitech k450x Quorum Technologies, UK).

\subsubsection{Statistical data analysis}

2.2.4. Statistička obrada podataka

Data collected from mechanical tests were analyzed by SPSS Software Package on the basis of a one- way analysis of variance. The mean values were compared by Duncan's multiple range test at the $95 \%$ confidence level.

\section{RESULTS AND DISCUSSION 3. REZULTATI I RASPRAVA}

According to Figure 1, the addition of $15 \%$ fibers to PLA increased the tensile modulus of PLA/natural fibers composites. The addition of more natural fibers (30\%) brought about higher stiffness of composites. As NG was applied, tensile modulus of composites kept its ascending trend. When NG level was increased from $0.75 \%$ to $1.5 \%$, the highest tensile modulus was obtained among all composites, whilst further increases in NG up to $3 \%$ resulted in the loss of tensile modulus as compared to the composites containing $1.5 \%$ NG. The highest tensile modulus or stiffness was related to PLA composites with $30 \%$ natural fibers and $1.5 \% \mathrm{NG}$, which was $30 \%$ higher than that of $67 \%$. PLA70/F30 composites resulted in tensile modulus higher by about $32 \%$ than the PLA83.5/F15/NG1.5 composites. It can be claimed that NG had higher stiffness than matrix polymer, which was the reason for the higher stiffness of PLA/natural fibers composite (Puglia et al., 2004). Statistical surveys indicate significant changes in tensile modulus with the variations of fiber/ $\mathrm{NG}$ ratio. Duncan classification shows that the addition of fibers and NG to pure PLA entailed significant differences among various groups. Duncan test classified pure PLA in a separate project, while the use of fibers at $15 \%$ and three various levels of NG did not present much difference and all projects were almost placed in one class. However, the application of $30 \%$ fibers and various rates of $\mathrm{NG}$ resulted in greater differences among classes.

The analysis of the tensile strength of fabricated composites and their comparison to each other and to pure PLA revealed that, when $15 \%$ wood fibers were added to PLA composites, the tensile strength of composites was diminished. Even when NG was added to composite structures at the rates of $0.75,1.5$, and $3 \%$, their tensile strength was lower than that of pure PLA. The reduction in the tensile strength of polymer with the addition of natural fibers has been confirmed in several studies (Nourbakhsh and Ashori, 2009). The addition of $30 \%$ wood fiber to PLA decreased the tensile strength as did the addition of $15 \%$ wood fiber. The addition of $0.75 \% \mathrm{NG}$ to composites increased the tensile strength as compared to the pure PLA and graphene-free composites. A higher level of tensile strength was observed in PLA68.5/F30/NG1.5 composites. The tensile strength of these composites was $26 \%$ higher than that of PLA composites containing 15 $\%$ wood fiber and $1.5 \%$ NG (PLA83.5/F15/NG1.5 composites) and $46 \%$ higher than that of PLA composites containing $30 \%$ wood fiber (PLA68.5/F30/NG1.5 composites). According to statistical analysis, the changes in the tensile strength were significant. Sun et al. (2005) reported that the rate of fibers and interfacial adhesion affected the tensile strength. It can be said 


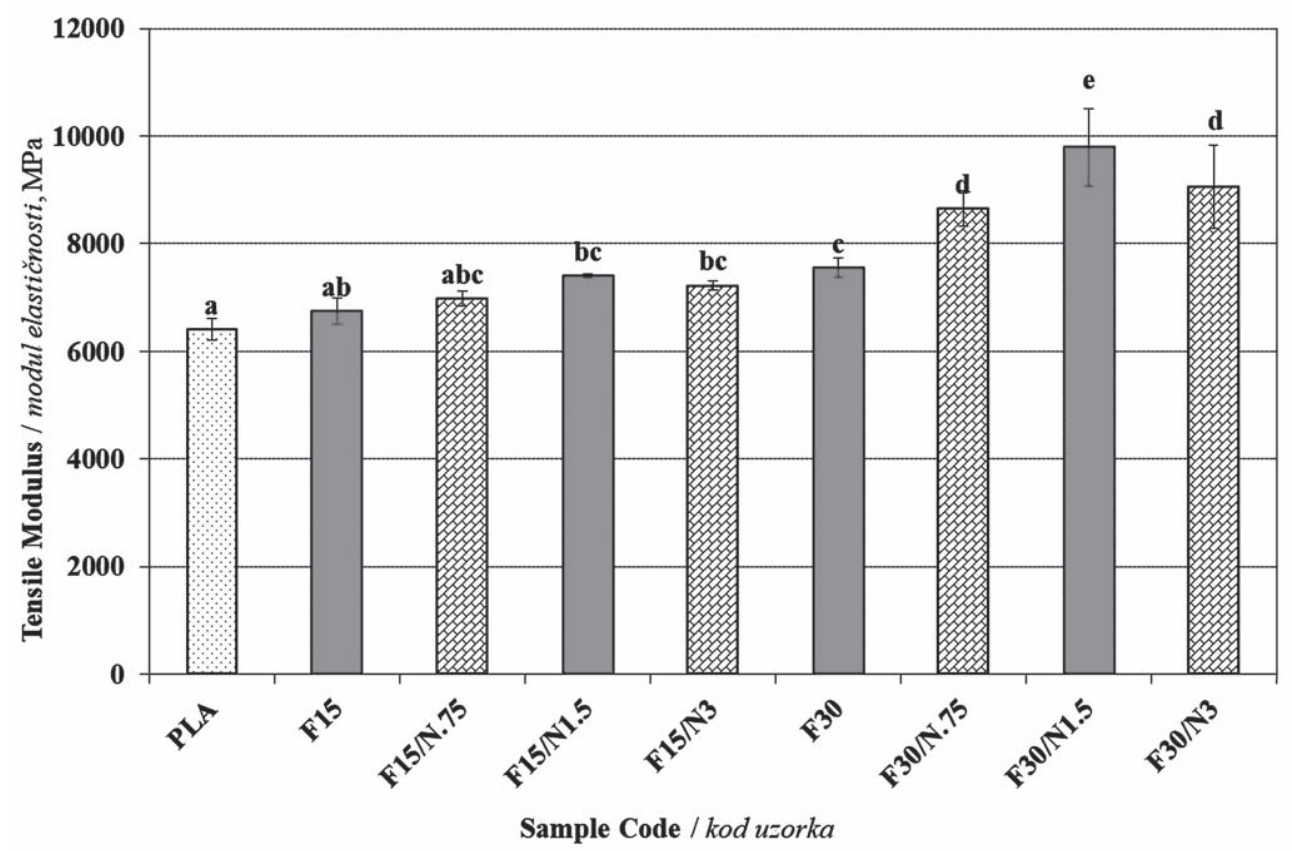

Figure 1 Tensile modulus of PLA/ wood fibers /NG composites. Letters above bars denote Duncan classification Slika 1. Modul elastičnosti kompozita proizvedenih od PLA, drvnih vlakana i nanografena (slova iznad stupaca prikazuju Duncanovu klasifikaciju)

that, in addition to the application of NG to composite structures, the rate of wood fiber application can be a determinant of tensile strength. The enhancement of tensile properties among composites containing NG can be related to the higher apparent coefficient and high interfacial areas (Balandin et al., 2008).

The overuse of NG (i.e., $3 \%$ ) resulted in the accumulation of this particle in composite structures and decreased the composite properties as compared to composites containing $1.5 \% \mathrm{NG}$. The proper distribution of NG in composite structures has been reported in several studies (Chang et al., 2005; Coleman et al.,
2006).These results demonstrate the better interfacial behavior between fibers and PLA. The enhancement of tensile properties of composites containing nanoparticles is in agreement with previous studies (Li et al., 2011; Hajian et al., 2012; Mohamadi et al., 2013). The significant difference in different groups can be clearly seen in Duncan classification.

Figure 3 shows the variation of bending modulus of the compositions used in the fabrication of PLA composites. The same as seen in tensile modulus in the study on the bending modulus of the fabricated composites and pure PLA, it was revealed that the bending

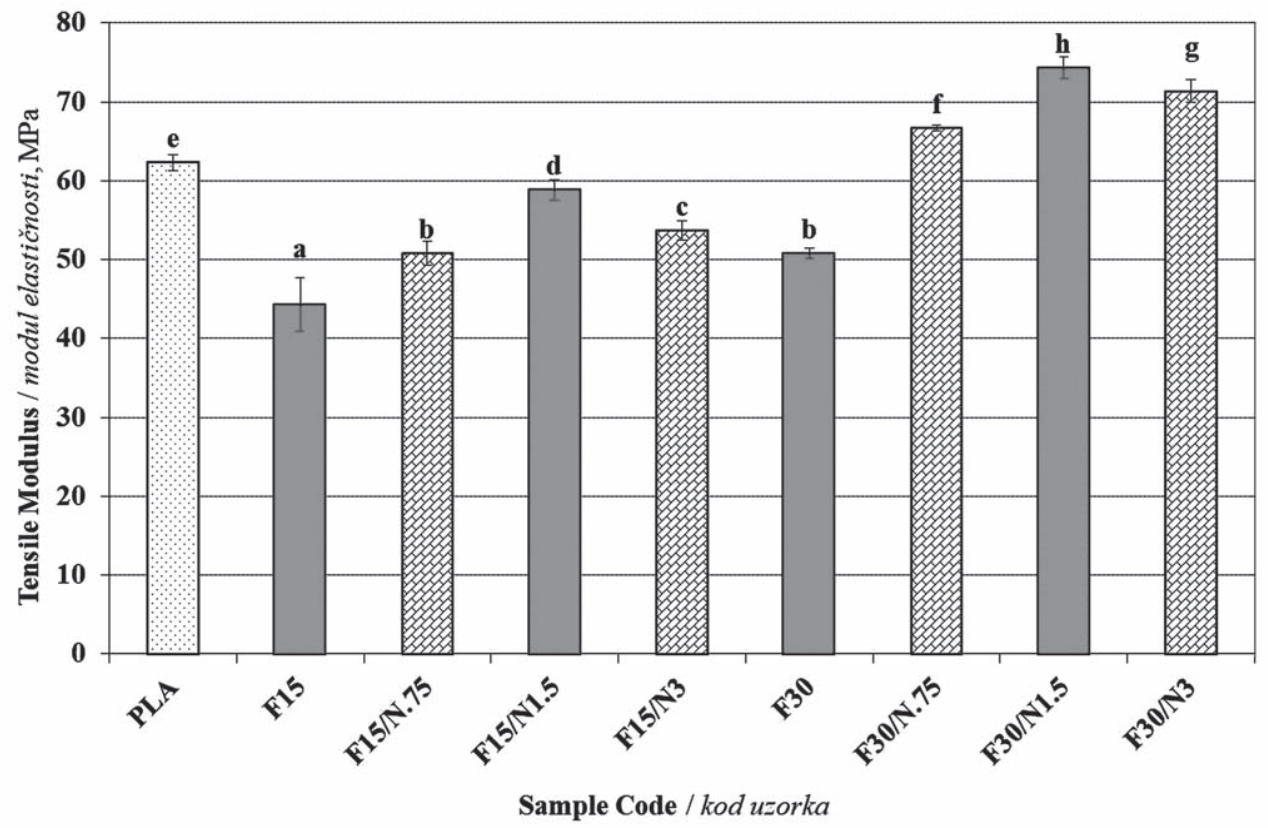

Figure 2 Tensile strength of PLA/wood fiber/NG composites. Letters above bars denote Duncan classification Slika 2. Vlačna čvrstoća kompozita proizvedenih od PLA, drvnih vlakana i nanografena (slova iznad stupaca prikazuju Duncanovu klasifikaciju) 


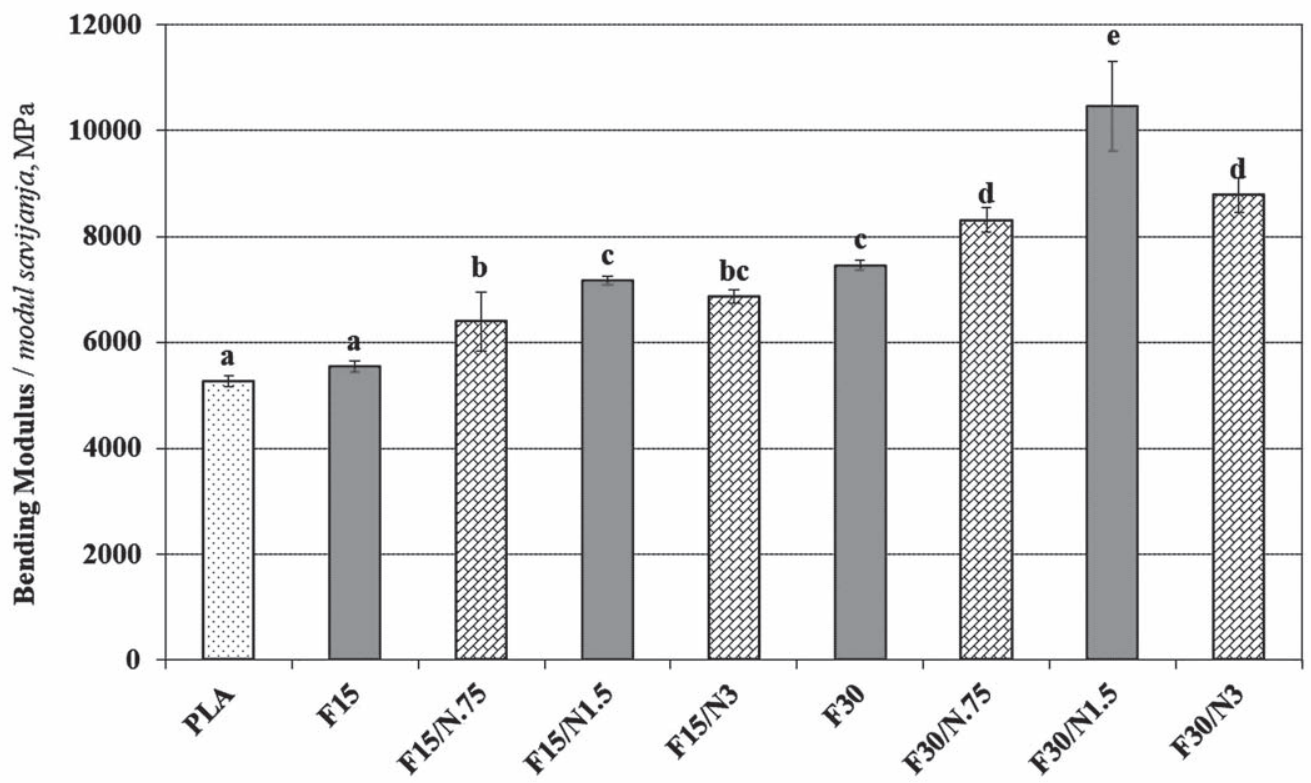

Sample Code / kod uzorka

Figure 3 Bending modulus of PLA/wood fiber/NG composites. Letters above bars denote Duncan classification Slika 3. Modul savijanja kompozita proizvedenih od PLA, drvnih vlakana i nanografena (slova iznad stupaca prikazuju Duncanovu klasifikaciju)

modulus was increased considerably as wood fiber was applied to PLA. By increasing wood fiber from $15 \%$ to $30 \%$ in composite compositions, the bending modulus was remarkably improved. Nevertheless, the addition of NG increased the significance of PLA composites (GhajeBeigloo et al., 2017; Chaharmahali et al., 2014). The composites containing $30 \%$ wood fiber and $1.5 \%$ $\mathrm{NG}$ indicated the highest bending modulus. Adding 1.5 $\%$ NG to PLA68.5/F30 composite into wood structure, fiber showed a $99 \%$ increase as compared to pure PLA and a $46 \%$ increase as compared to PLA83.5/F15/ NG1.5 composites. Duncan classification showed no significant difference in stiffness between pure PLA and composites containing PLA percentages and $15 \%$ fibers. These two structures were placed in one class, while the addition of $\mathrm{NG}$ and the application of $30 \%$ fibers rendered the difference between classes significant, so that they were placed in separate classes.

Figure 4 indicates that the addition of 15 or $30 \%$ wood fiber did not improve bending strength of PLA composites when compared with pure PLA. On the other hand, none of the studied rates of NG could increase bending strength to that of pure PLA. The application of $\mathrm{NG}$ at the rate of $30 \%$ of fibers applied in

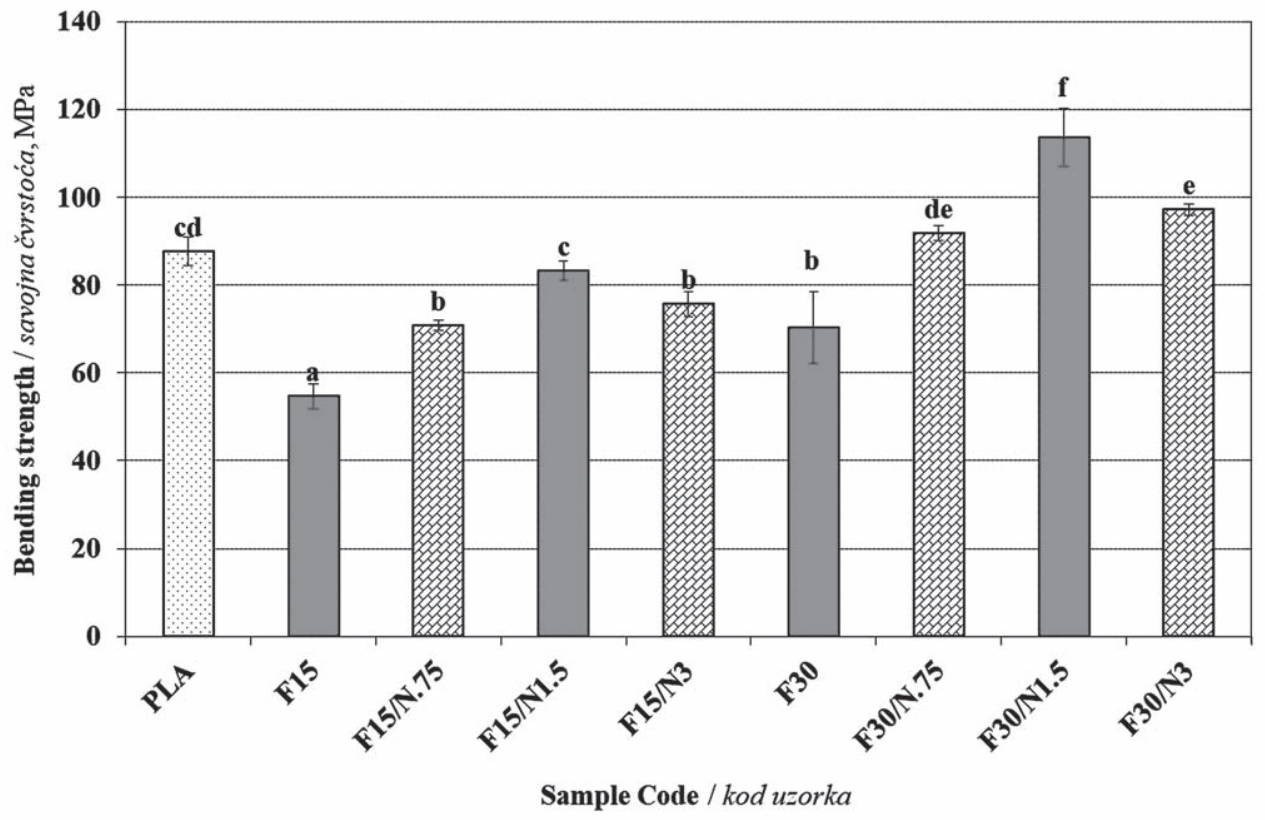

Figure 4 Bending strength of PLA/wood fiber/NG composites. Letters above bars denote Duncan classification Slika 4. Čvrstoća savijanja kompozita proizvedenih od PLA, drvnih vlakana i nanografena (slova iznad stupaca prikazuju Duncanovu klasifikaciju) 


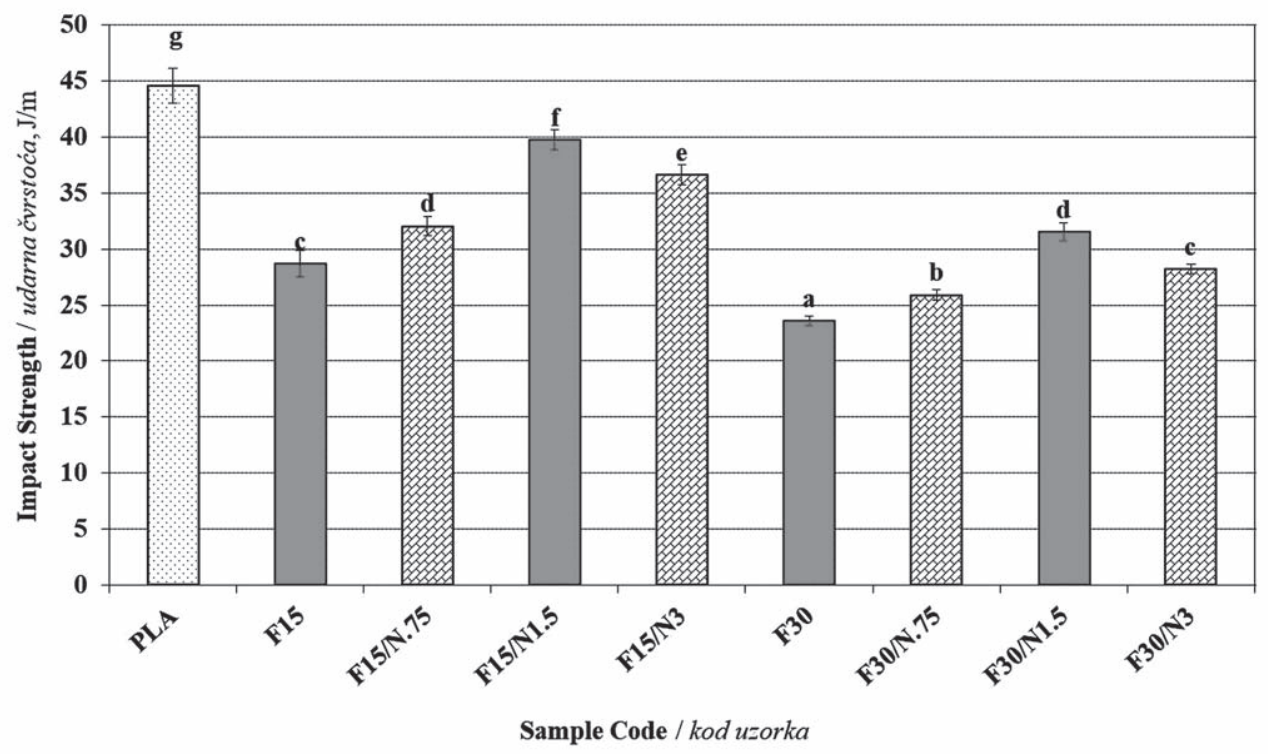

Figure 5 Impact strength of PLA/wood fiber/NG composites. Letters above bars denote Duncan classification Slika 5. Udarna čvrstoća kompozita proizvedenih od PLA, drvnih vlakana i nanografena (slova iznad stupaca prikazuju Duncanovu klasifikaciju)

PLA composites resulted in a good improvement of PLA composites. One of the most important factors in composite fabrication with NG is the distribution of nanoparticles across the matrix. Improper distribution of nanoparticles can decrease the NG composite properties at high rates of $\mathrm{NG}$ application in $\mathrm{NG}$ composites (Sheshmani and Amini, 2013). Moreover, the higher bending properties in composites containing $1.5 \% \mathrm{NG}$ as compared to other compositions can be attributed to higher stiffness, higher apparent coefficient, and higher interfacial connections.

Amani and Seshmani (2013) reported that the application of high rates of NG did not improve the bending properties due to the accumulation of nanoparticles. Statistical surveys showed significant changes in bending properties (modulus and strength) with the variations of the level of fibers and NG. According to the Duncan classification, the use of $1.5 \%$ NG and 15 $\%$ fibers could enhance the bending strength to as high as that of pure PLA and these two classes were nearly placed in one class and higher rates of fibers and nanoparticles application increased the bending strength as compared to pure PLA.

Figure 5 depicts the amounts and trend of impact strength of fabricated composites. The strength of material against breakage and the crack initiation and gap in weak spots reflects the impact strength of composites. These weak spots are mainly located at the interface of fibers and polymer. The application of wood fiber decreased PLA composite impact strength as compared to pure PLA. The enhancement of composite impact strength, achieved by increasing wood fiber, can be related to the accumulation of wood fiber in composite structures (Nourbakhshand Ashori, 2009). Nevertheless, the application of NG could not increase the impact strength to a level as high as that of pure PLA. However, it should be noted that the application of NG increased the impact strength to a greater extent in PLA composites than in PLA-free composites. Among fabricated composites, PLA83.5/F15/NG1.5 composites had the highest impact strength. When NG is increased by more than $1.5 \%$, the stress is concentrated and, consequently, some cracks are created in the composites. In a study on polymer/fibers/NG composites, Sheshmani et al. (2013) reported lower impact strength of composites at the presence of NG. Duncan classification shows significant differences between groups and classifies each one in a separate class.

\subsection{Morphology}

3.1. Morfologija

To better analyze the results and study the morphology of break level and interstitial area of polymer and wood fiber, electron imagery was prepared by SEM system from break sections of module in bending test.

Figure 6 shows the distension of fibers from the matrix and the porosity between the matrix and fibers. It presents a weak connection area between the two phases, where there was no proper adhesion between the polymer and the matrix, finally proving weaker composite properties than the other compositions.

In spite of the presence of $1.5 \% \mathrm{NG}$ in the composition of PLA and $15 \%$ wood fiber, the fibers flow out the matrix with lower rate and less pores. Moreover, the images show that NG settled on matrix more than fibers, implying better union between NG and matrix than between NG and fibers. Also, NG did not accumulate.

Figure 6.C shows the PLA82/F15/NG3 composites with fracture surface. As can be seen, NG did not accumulate. The accumulation of NG results in the loss of adhesion between matrix and NG and the loss of proper distribution of NG on fibers and matrix. Finally, the connection does not emerge between the two phases leading to the fracture and distension of fibers from the matrix. 

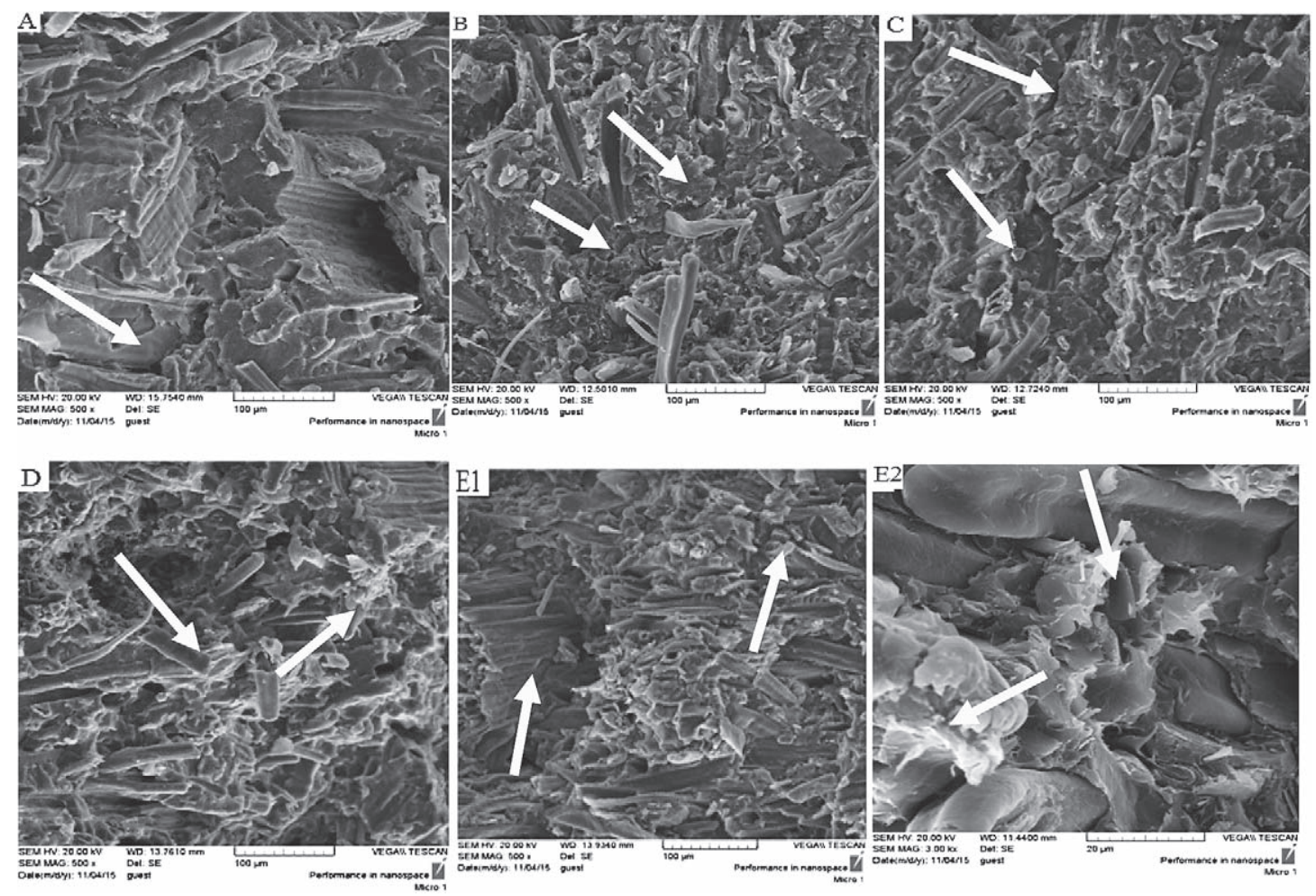

Figure 6 A: PLA85/F15 composites; B: PLA83.5/F15/NG1.5 composites; C: PLA82/F15/NG3 composites; D: PLA70/F30 composites; E1 and E2: PLA68.5/F30/NG 1.5 composites

Slika 6. Prikaz kompozita dobiven skenirajućim elektronskim mikroskopom: A - kompozit PLA85/F15; B - kompozit PLA83.5/F15/NG1.5; C - kompozit PLA82/F15/NG3; D - kompozit PLA70/F30 composites; E1 i E2 - kompozit PLA68.5/ F30/NG 1.5

Figure 6.D presents the fracture surface of samples from PLA composites, which shows porosity like PLA70/F30 composites. Here, however, because of the presence of more fibers, the distension is lower, since the fibers are closer to each other. The fractures show a weak connection surface between the two phases.

Figures 6.E1 and E2 show a connection of good interface surface between two sample phases of PLA68.5/F30/NG1.5 composites. Figure 6E clearly shows that the use of $30 \%$ wood fiber resulted in higher uptake of NG and that NG can settle on matrix and fibers, causing the adhesion of interface between fibers and matrix. Here, no accumulation of NG was observed. The good distribution of fibers among the matrix and NG among the fibers and matrix was the reason for this good interface connection between the two phases (it can clearly be seen in Figure 6E2). Finally, it results in more effective transfer of tension from the matrix to fibers. It is the effect of NG on fibers and matrix that caused the adhesion of interface surfaces. The highest mechanical properties were observed in these composites.

\section{CONCLUSIONS}

4. ZAKLJUČAK

The application of natural fiber in the PLA matrix increased the stiffness of PLA/natural fiber composites. The increase in fibers from $15 \%$ to $30 \%$ in composite structures improved the stiffness of the composites. The use of $30 \%$ fibers and $1.5 \%$ NG (PLA68.5/
F30/NG1.5 composites) resulted in the highest stiffness among composites.

As fiber (15\%) was applied to PLA composites, its tensile and bending strength was decreased as compared to pure PLA, whilst further enhancements of fibers to $30 \%$ improved the tensile and bending strength. PLA68.5/F30/NG1.5 composites exhibit the highest tensile and bending strength.

The results of impact strength tests revealed that the use of natural fibers at two rates of 15 and $30 \%$ decreased the impact strength of PLA/natural fiber composites and even the use of NG could not improve the impact strength of PLA composites as compared to that of pure PLA.

The SEM images show that the application of 30 $\%$ fibers resulted in lower outflow of fibers from matrix and their better dispersion in matrix when compared with the application of $15 \%$ fibers. Moreover, the application of NG at the rate of $1.5 \%$ presented better dispersion of fibers in matrix than other rates of NG.

\section{REFERENCES}

5. LITERATURA

1. Ansari, S.; Giannelis, E. P., 2009: Functionalized graphene sheet poly(vinylidene fluoride) conductive nanocomposites. Journal of Polymer Science Part B: Polymer Physics, 47 (9): 888-897.

https://doi.org/10.1002/polb.21695.

2. Bledzki, A. K.; Jaszkiewicz, A., 2010: Mechanical performance of biocomposites based on PLA and PHBV reinforced with natural fibres - A comparative study to 
PP, Composites Science and Technology. Composites Science and Technology, 70 (12): 1687-1696. https://doi.org/10.1016/j.compscitech.2010.06.005.

3. Balandin, A. A.; Ghosh, S.; Bao, W.; Calizo, I.; Teweldebrhan, D., 2008: Superior thermal conductivity of single-layer graphene. Nano Letter, 8: 902-907. https://doi.org/10.1021/n10731872.

4. Chang, T. E.; Jensen, L. R.; Kisliuk, A.; Pipes, R. B.; Pyrz, R; Sokolov, A. P., 2005: Microscopic mechanism of reinforcement in single-wall carbon nanotube/polypropylene nanocomposite. Polymer, 46 (2): 439-444. https://doi.org/10.1016/j.polymer.2004.11.030.

5. Coleman, J. N.; Khan, U.; Gunko, Y. K., 2006: Mechanical reinforcement of polymers using carbon nanotubes. Advanced Materials, 18 (6): 689-706.

https://doi.org/10.1002/adma.200501851.

6. Chaharmahali, M.; Hamzeh, Y.; Ebrahimi, G.; Ashori, A.; Ghasemi, I., 2014: Effects of nano-graphene on the physico-mechanical properties of bagasse/polypropylene composites. Polymer Bulletin, 71 (2): 337-349. https://doi.org/10.1007/s00289-013-1064-3

7. Ghaje Beigloo, J.; Eslam, H. K.; Hemmasi, A. H.; Bazyar, B.; Ghasemi, I., 2017: Effect of Nanographene on Physical, Mechanical, and Thermal Properties and Morphology of Nanocomposites Made of Recycled High Density Polyethylene and Wood Flour. BioResources, 12 (1): 1382-1394. https://doi.org/10.15376/biores.12.1.1382-1394.

8. Hajian, M.; Reisi, M. R.; Koohmareh, G. A.; Jam, A. R. Z., 2012: Preparation and characterization of polyvinylbutyral/graphene nanocomposite. Journal of Polymer Research, 19 (10): 1-7. https://doi.org/10.1007/s10965-012-9966-6.

9. Kim, H.; Macosko, C. W., 2009: Processing-property relationships of polycarbonate/graphene composites. Polymer, 50 (15): 3797-3809. https://doi.org/10.1016/j.polymer.2009.05.038.

10. Lin, Y.; Jin, J.; Song, M., 2011: Preparation and characterization of covalent polymer functionalized graphene oxide. Journal of Materials Chemistry, 21: 3455-3461.

https://doi.org/10.1039/C0JM01859G.

11. Mohanty, A. K.; Misra, M.; Hinrichsen, G., 2000: Biofibres, biodegradable polymers and biocomposites: an overview. Macromolecular Materials and Engineering, 276-277 (1): 1-24. https://doi.org/10.1002/(SICI)14392054(20000301)276:1<1::AID-MAME1>3.0.CO;2-W.
12. Mohamadi, S.; Sharifi-Sanjani, N.; Foyouhi, A., 2013: Evaluation of graphenenanosheets influence on the physical properties of PVDF/PMMA blend. Journal of Polymer Research, 20 (1): 1-10.

https://doi.org/10.1007/s10965-012-0046-8.

13. Nourbakhsh, A.; Ashori, A., 2009: Influence of nanoclay and coupling agent loading on the physical mechanical properties of bagasse/PP nanocomposite. Applied Polymer Science, 112 (3): 1386-1390.

https://doi.org/10.1002/app.29499.

14. Petinakis, E.; Yu, L.; Edward, G.; Dean, K.; Liu, H.; Andrew, D., 2009: Effect of Matrix-Particle Interfacial Adhesion on the Mechanical Properties of Poly (lactic acid) /Wood-Flour Micro-Composites. Journal of Polymers and the Environment, 17: 83-94.

DOI: https://doi.org/10.1007/s10924-009-0124-0.

15. Puglia, D.; Biagiotti, J.; Kenny, J. M., 2004: A review on natural fibrebased composites-part II: application of natural reinforcements in composite materials for automotive industry. Journal of Natural Fibers, 1 (3): 23-65. https://doi.org/10.1300/J395v01n03_03.

16. Sheshmani, S.; Amini, R., 2013: Preparation and characterization of graphene based nanocomposite materials. Carbohydrate Polymers, 95 (1): 348-359. https://doi.org/10.1016/j.carbpol.2013.03.008.

17. Sheshmani, S.; Ashori, A. Arab.; Fashapoyeh, M., 2013: Wood plastic composite using graphenenanoplatelets. International Journal of Biological Macromolecules, 58: 1-6. https://doi.org/10.1016/j.ijbiomac.2013.03.047

18. Sun, S.; Li, C.; Zhang, L.; Du, H. L.; Burnell Gray, J. S., 2005: Interfacial structures and mechanical properties of PVC composites reinforced by $\mathrm{CaCO}_{3}$ with different particle sizes and surface treatments. Polymer International, 55 (2): 158-164. https://doi.org/10.1002/pi.1932

\section{Corresponding address:}

Assist. Prof. BEHZAD BAZYAR, Ph.D.

Department of Wood and Paper Science and Technology College of Agriculture and Natural Resources

Science and Research Branch

Islamic Azad University

Teheran, IRAN

e-mail: bazyar@srbiau.ac.ir 